\section{Particulate matter and hospital admission due to arterial hypertension in a medium-sized Brazilian city}

\author{
Material particulado e internação hospitalar por \\ hipertensão arterial em uma cidade brasileira \\ de porte médio
}

\author{
Material particulado e internamiento hospitalario \\ por hipertensión arterial en una ciudad brasileña \\ de porte medio
}

Luiz Fernando Costa Nascimento 1 Juliana Batrov Francisco 1

\section{${ }^{1}$ Universidade de Taubaté, Taubaté, Brasil. \\ Correspondence L. F. C. Nascimento Universidade de Taubaté. Av. Tiradentes 500, Taubaté, SP 12030-180, Brasil.}

luiz.nascimento@unitau.b

\section{Abstract}

This study aims to assess the effects air pollution on hospitalization due to hypertension. An ecological study was conducted using data regarding hospitalizations due to hypertension in São José dos Campos, State of São Paulo, Brazil between January 1, 2007 and December 31, 2010. The pollutants analyzed by this study were particulate matter, sulfur dioxide and ozone. A significant association between exposure to particulate matter and hospitalization due to hypertension was identified using Poisson regression with lags of up to four days. Relative risk of hospital admission ranged between 1,009 and 1,019. A 10 $\mathrm{\mu g} / \mathrm{m}^{3}$ increase in concentration of particulate matter was associated with a $13 \%$ increase in risk of hospitalization.

Air Pollution; Particulate Matter; Hypertension; Cardiovascular Diseases

\section{Resumo}

Alguns dos efeitos da poluição ambiental na saúde humana são conhecidos, destacando aqueles no sistema cardiovascular. Este trabalho tem por objetivo estimar esses efeitos nas internações por hipertensão arterial. Foi um estudo ecológico realizado com dados de internações da cidade de São José dos Campos, São Paulo, Brasil, relativos aos diagnósticos de hipertensão arterial, entre 10 de janeiro de 2007 e 31 de dezembro de 2010. Os poluentes estudados foram material particulado, dióxido de enxofre e ozônio. Utilizando-se de modelo linear generalizado da regressão de Poisson e defasagens de até quatro dias, foi possivel identificar associação significativa entre a exposição ao material particulado e a internação por hipertensão, com os riscos variando entre 1.009 e 1.019; aumento de $10 \mu \mathrm{g} / \mathrm{m}^{3}$ desse poluente aumenta o risco de internação em até 13\%. Assim foi possivel identificar o material particulado, no modelo multipoluente, como associado à internação por hipertensão arterial numa cidade de porte médio, como São José dos Campos.

Poluição do Ar; Material Particulado; Hipertensão; Doenças Cardiovasculares 


\section{Introduction}

Epidemiological studies have shown a consistent increase in the risk of cardiovascular morbidity and mortality associated with exposure to particulate matter $\left(\mathrm{PM}_{10}\right)$ 1. Hypertension, in addition to being an important risk factor for death from heart disease, is also a contributing factor to cerebrovascular disease 2 . Half of heart attacks occur as a result of this disease and almost $100 \%$ of individuals that experience heart failure have a history of hypertension. Furthermore, $67 \%$ of patients suffering from cerebrovascular disease had diastolic and systolic blood pressure of $\geq 90 \mathrm{~mm}$ $\mathrm{Hg}$ and $140 \mathrm{mmHg}$, respectively 3 .

In 2009, the Brazilian Unified National Health System (SUS) reported more than 100,000 hospital admissions due to hypertension with an associated cost of over $\mathrm{R} \$ 28$ million. Over 20,000 of these admissions occurred in the State of São Paulo and related spending amounted to over R\$ 8 million ( 1 US $\$ \approx R \$ 1.70$ ). In the same period, over 44,000 deaths due to hypertension were reported in Brazil, of which approximately 8,000 were in the State of São Paulo (Departamento de Informática do SUS. http://tabnet.datasus.gov. br/cgi/tabcgi.exe?sih/cnv/nruf.def and http:// tabnet.datasus.gov.br/cgi/tabcgi.exe?sim/cnv/ obt10uf.def, accessed on 20/Jul/2012).

It is believed that the impact of $\mathrm{PM}_{10}$ exposure on blood pressure is an important contributing factor to the onset of adverse effects on the cardiovascular system and several articles have reported an association between fluctuations in $\mathrm{PM}_{10}$ levels and blood pressure. This association has been explained by a number of biological mechanisms, including acute arterial vasoconstriction after exposure to fine particles with added ozone 4,5,6,7.

The exposure of individuals to air with fine particles and ozone, as opposed to clean air, leads to a significant increase in blood pressure due to the carbon content of the particulate matter. Although further research is needed into the biological mechanisms that cause this change, there is an apparent association between vehicular traffic and risk of cardiovascular disease 5 .

A study conducted in Beijing, China, showed that a $10 \mu \mathrm{g} / \mathrm{m}^{3}$ increase in $\mathrm{PM}_{10}$ concentrations resulted in an increase in emergency admissions duetohypertension $(\mathrm{OR}=1.06 ; 95 \% \mathrm{CI}: 1.02-1.10)^{6}$. In Santo André, São Paulo, Brazil, the systolic blood pressure of traffic controllers exposed to particulate matter increased by $2 \mathrm{mmHg}$ in the first hours after exposure 7 .

The objective of this study was to estimate the effect of exposure to particulate matter with an aerodynamic diameter of 10 microns or less
$\left(\mathrm{PM}_{10}\right)$ on hospital admissions due to hypertension in São José dos Campos in the State of São Paulo.

\section{Methodology}

This investigation consists of an ecological time-series study of hospital admissions due to hypertension (ICD-10: I10-15) among residents of São José dos Campos in the period January 1, 2007 to December 31, 2010. Data regarding daily hospital admissions was obtained from the Department of Health Informatics (DATASUS, http://www.datasus.gov.br). Daily $\mathrm{PM}_{10}$, sulfur dioxide $\left(\mathrm{SO}_{2}\right)$ and ozone $\left(\mathrm{O}_{3}\right)$ concentrations were estimated in $\mu \mathrm{g} / \mathrm{m}^{3}$ using data extracted from the site of the State of São Paulo Environmental Agency (CETESB). Since concentration measures are taken from a single monitoring station located in the downtown area, concentrations of pollutants were considered homogeneous across the entire city. Temperature and relative air humidity data was also obtained from this source.

São José dos Campos is located in the Southeastern Region of Brazil between the cities of São Paulo and Rio de Janeiro (23 $11^{\prime}$ South and $45^{\circ} 53^{\prime}$ West) and has a population of approximately 700,000 inhabitants. The city is an industrial, shopping and service center that serves towns in the Paraíba Valley and State of Minas Gerais with a total population of approximately two million inhabitants. The Dutra Highway, considered the most important highway in Brazil, runs through the city. The highway carries approximately 130,000 vehicles per day, including a large volume of heavy vehicles and buses.

Data was analyzed using Poisson regression: the dependent variable was the number of daily admissions due to hypertension and the independent variables were the pollutant concentration levels and the control variables were minimum temperature and relative humidity. A cubic spline was adopted to control for trend, and we used four degrees of freedom to smooth the trend.

Since the clinical manifestations of exposure to pollutants are believed to present a lag effect, whereby an individual may present health problems on the day of exposure or some days after, we adopted a structure with up to four days of lag (lag 0 to lag 4 ).

The correlation between the dependent and independent variables was defined based on the Pearson correlation coefficient.

For each lag structure, an isolated assessment of $\mathrm{PM}_{10}$ concentrations was made through the 
creation of a "unipollutant model" which was then adjusted for $\mathrm{SO}_{2}$ and $\mathrm{O}_{3}$ using "multipollutant models". The results of the Poisson regression represent the risk of hospital admission due to hypertension. The percentage increase in risk was estimated using a $95 \%$ confidence interval (95\%CI) based on a $10 \mu \mathrm{g} / \mathrm{m}^{3}$ increment in $\mathrm{PM}_{10}$ concentrations using the following formula: $\left.\mathrm{RI}=\left[\exp \left(\mathrm{b}_{1}{ }^{*} 10\right)-1\right) * 100\right]$, where $\mathrm{RI}$ is the percentage increase in risk and $\mathrm{b}_{1}$ is the $\mathrm{PM}_{10}$ coefficient. Data was analyzed using the software Stata, version 9 (Stata Corp., College Station, USA).

\section{Results}

A total of 606 hospital admissions occurred during the period with a daily mean of 0.41 (SD = 0.74); mean values with standard deviations, and minimum and maximum values are shown in Table 1. Pollutant data was missing on less than $5 \%$ of the days. Table 2 shows the correlation between the study variables and their $\mathrm{p}$-values and the correlation between hospital admissions and air pollutants.

Table 3 shows the results of the Poisson regression to assess the relative risk of hospital admission due to hypertension associated with $\mathrm{PM}_{10}$ concentration and adjusted for the other pollutants, divided into lags of zero to four days. Exposure to $\mathrm{PM}_{10}$ was associated with hospital admission for all lags using both the unipollutant and multipollutant models. The risk of hospital admission was between $1 \%$ and $2 \%$.

The relative risk of hospitalizations due to hypertension increased between $9 \%$ and $13 \%$ with a $10 \mu \mathrm{g} / \mathrm{m}^{3}$ increment in $\mathrm{PM}_{10}$ concentrations (Figure 1).

Table 1

Mean values, standard deviation and range of variables. São José dos Campos, State of São Paulo, Brazil 2007 to 2010.

\begin{tabular}{lcc}
\hline Variable [missing records] & Mean (SD) & Range \\
\hline Hospital admission [0] & $0.41(0.74)$ & $0-6$ \\
$\mathrm{PM}_{10}\left(\mu \mathrm{g} / \mathrm{m}^{3}\right)[41]$ & $24.1(12.2)$ & $7-89$ \\
$\mathrm{SO}_{2}\left(\mu \mathrm{g} / \mathrm{m}^{3}\right)[65]$ & $2.96(2.2)$ & $1-27$ \\
$\mathrm{O}_{3}\left(\mu \mathrm{g} / \mathrm{m}^{3}\right)[65]$ & $71.5(39.6)$ & $15-258$ \\
Temperature (०C) [14] & $28.7(4.4)$ & $15.4-32.3$ \\
Humidity (\%) [29] & $85.8(7.8)$ & $46.3-100.0$ \\
\hline
\end{tabular}

SD: standard deviation.

\section{Discussion}

To the best of our knowledge, this is the first study of the association between particulate matter exposure and hospital admissions due to hypertension carried out in a medium-sized city in Brazil. The results show that the effect of $\mathrm{PM}_{10}$ exposure is not controlled by exposure to the other pollutants considered by this study.

The risk of hospital admission found by this study ( $1 \%$ to $2 \%$ ) can be considered low. However, the results show a nine to $13 \%$ increase in risk with a $10 \mu \mathrm{g} / \mathrm{m}^{3}$ increase in $\mathrm{PM}_{10}$ concentrations depending on the time lag in question. It is important to note that the average concentration of this pollutant was considerably less than the minimum threshold recommended by the Brazilian Environment Council (Resolução CONAMA n. 03/1990) ${ }^{8}$ of $50 \mu \mathrm{g} / \mathrm{m}^{3}$. This threshold was exceeded on 132 days (9\%) of the study period.

Studies in São Paulo and São José dos Campos, have shown that exposure to a $10 \mu \mathrm{g} / \mathrm{m}^{3}$ increase in $\mathrm{PM}_{10}$ concentrations was associated with an increase in hospital admissions due to cardiovascular diseases in the elderly of almost $2 \%$ and $6 \%$, respectively 9,10 , and another recent study in Brazil showed an association between exposure to particulate matter and hospitalization due to stroke 11. Similar associations were also observed by an investigation of biomass burning in Araraquara and a study of a sample of traffic controllers in Santo André 7,12, and a number of other studies 6,7,13,14.

It is important to note that, although the findings of this study may suggest a relationship between variables, this does not necessarily mean that there is a clear causal effect.

Our decision to adopt minimum temperature as a control variable was based on the findings of Halonen et al. 15 that suggest that cumulative exposure to lower ambient temperatures may lead to an increase in blood pressure due to a mechanism triggered by the cold.

Poisson regression was also used by Arbex et al. 12 . Conceição et al. 16 showed that the difference between results obtained using linear and additive models of Poisson regression is nominal and another study found that the results obtained using time-series and case-crossover analysis are also largely similar 17 .

The number of hospital admissions was adopted as an indicator of effect on health since it is known that only the most severe cases require hospital admission. However, hypertensive patients seeking emergency services are often treated and released without being officially admitted for hypertension and it is therefore reasonable to assume that the real number of 
Table 2

Pearson's correlation matrix showing all variables. São José dos Campos, State of São Paulo, Brazil 2007 to 2010

\begin{tabular}{|c|c|c|c|c|c|}
\hline Variable & $\begin{array}{l}\text { Hospital } \\
\text { admission }\end{array}$ & $\mathrm{PM}_{10}$ & $\mathrm{SO}_{2}$ & $\mathrm{O}_{3}$ & Temperature $\left({ }^{\circ} \mathrm{C}\right)$ \\
\hline Hospital admission & 1.00 & & & & \\
\hline $\mathrm{PM}_{10}$ & 0.08 * & 1.00 & & & \\
\hline $\mathrm{SO}_{2}$ & 0.09 * & 0.50 * & 1.00 & & \\
\hline $\mathrm{O}_{3}$ & $0.11 *$ & 0.42 * & 0.28 * & 1.00 & \\
\hline Temperature $\left({ }^{\circ} \mathrm{C}\right)$ & -0.21 & 0.21 * & 0.04 & 0.44 * & 1.00 \\
\hline Humidity & $0.07 * \star$ & $-0.47 *$ & $-0,19$ * & -0.42 * & -0.33 * \\
\hline
\end{tabular}

* $\mathrm{p}<0.01$

${ }^{\star *} p<0.05$

Table 3

Relative risk of hospital admission due to hypertension with the respective $95 \%$ confidence interval $(95 \% \mathrm{Cl})$ showing the isolated effect of $\mathrm{PM}_{10}$ exposure and combined effect of other pollutants for each lag structure. São José dos Campos, State of São Paulo, Brazil 2007 to 2010.

\begin{tabular}{ccccc}
\hline & $\mathrm{PM}_{10}$ & $\mathrm{PM}_{10}+\mathrm{SO}_{2}$ & $\mathrm{PM}_{10}+\mathrm{O}_{3}$ & $\mathbf{P M}_{10}+\mathrm{SO}_{2}+\mathrm{O}_{3}$ \\
\hline $\operatorname{Lag} 0$ & $1.021(1.014-1.028)$ & $1.018(1.009-1.026)$ & $1.015(1.008-1.022)$ & $1.013(1.004-1.022)$ \\
$\operatorname{Lag} 1$ & $1.018(1.010-1.025)$ & $1.015(1.006-1.023)$ & $1.010(1.003-1.0180$ & $1.009(1.001-1.018)$ \\
$\operatorname{Lag} 2$ & $1.020(1.012-1.028)$ & $1.015(1.007-1.024)$ & $1.013(1.006-1.021)$ & $1.010(1.002-1.019)$ \\
$\operatorname{Lag} 3$ & $1.018(1.010-1.025)$ & $1.016(1.008-1.024)$ & $1.013(1.005-1.020)$ & $1.012(1.004-1.021)$ \\
$\operatorname{Lag} 4$ & $1.019(1.011-1.026)$ & $1.016(1.008-1.024)$ & $1.012(1.005-1.020)$ & $1.011(1.002-1.019)$ \\
\hline
\end{tabular}

Figure 1

Relative risk (RR) of hospital admission due to hypertension related to a $10 \mu \mathrm{g} / \mathrm{m}^{3}$ increase in particulate matter concentration with respective $95 \%$ confidence intervals $(95 \% \mathrm{Cl})$ for each day of the lag structure (multipollutant model). São José dos Campos, State of São Paulo, Brazil, 2007 to 2010.

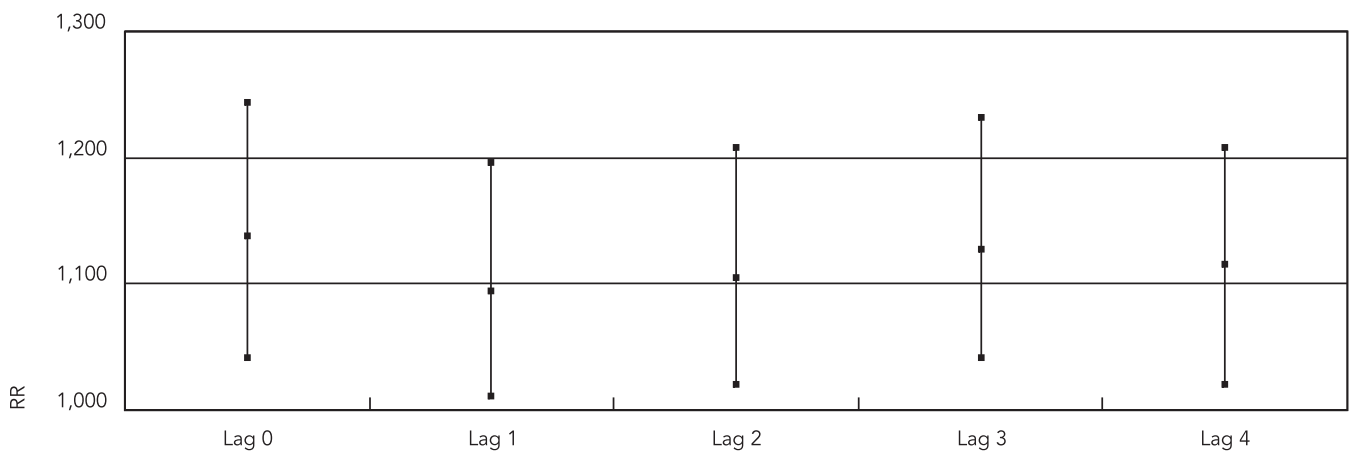


affected people is larger. We considered outpatients and patients from emergency clinics belonging to the public health system.

The following points should be noted: first, hypertension medication may alter the response to $\mathrm{PM}_{10}$ exposure; second, the information on admissions due to hypertension only includes patients attended by the SUS. Those hospitalized under private health plans are excluded and, since coverage by the SUS is around $85 \%$ of the population, it is possible that the sample does not reflect the real number of hospitalizations due to hypertension; thirdly, the primary aim of DATASUS is to gather information for accounting purposes. However, this source is commonly used by studies on the human health effects of exposure to air pollutants 9,10,18,19.

The mechanisms underlying particulate matter exposure and hypertension are still poorly understood. Vasoconstriction may be associated with an increase in the activity of the reflex sympathetic nervous system due to the stimulation of pulmonary vagal afferents 20 . An increase in plasma endothelin levels and systemic inflammatory cytokine production possibly related to the free radical activity of components of particulate matter could also lead to increased blood pressure ${ }^{4}$. Another explanation is that increased peripheral vascular resistance is likely to mediate these changes, whereas increased baroreceptor reflex sensitivity may compensate for changes in blood pressure induced by particles 21 .

This study has the following possible limitations: clinical diagnosis errors; the time lapse between symptoms and admission to hospital; lack of information on factors commonly associated with hypertension, such as smoking, sedentary lifestyle and overweight; the assumption that the concentration of pollutants is homogeneous throughout the city does not take into account the differing concentration levels throughout the city.

It is also important to note that individuals with a history of hypertension may have other cardiovascular diseases and the use of medications for such diseases can modify individual response to particulate matter exposure 22 . In this respect, the indicator hospitalization due to hypertension may have low sensitivity for evaluating the effect of exposure to particulate matter 12 .

Despite the above considerations, this study confirms that the exposure to particulate matter at concentrations under the minimum threshold recommended by Brazilian law plays a role in hospital admission due to hypertension.

\section{Resumen}

Algunos de los efectos de la contaminación ambiental en la salud humana son conocidos, destacando aquellos en nuestro sistema cardiovascular. Este trabajo tiene por objetivo estimar esos efectos en los internamientos por hipertensión arterial. Se trató de un estudio ecológico, realizado con datos de internamientos de la ciudad de São José dos Campos, São Paulo, Brasil, relativos a los diagnósticos de hipertensión arterial, entre el 1o de enero de 2007 y el 31 de diciembre de 2010. Los contaminantes estudiados fueron material particulado, dióxido de azufre y ozono. Se utilizó un modelo lineal generalizado de regresión de Poisson y desfases de hasta cuatro días; fue posible identificar una asociación significativa entre la exposición al material particulado y el internamiento por hipertensión con los riesgos, variando entre 1.009 y 1.019; el aumento de $10 \mu \mathrm{g} / \mathrm{m}^{3}$ de ese contaminante aumenta el riesgo de internamiento en hasta un 13\%. Así, fue posible identificar el material particulado, en el modelo multicontaminante, como asociado al internamiento por hipertensión arterial en una ciudad de porte medio, como São José dos Campos.

Contaminación del Aire; Material Particulado; Hipertensión; Enfermedades Cardiovasculares 


\section{Contributors}

L. F. C. Nascimento and J. B. Francisco contributed towards the elaboration of this project, discussion of data and drafting the final version of this article.

\section{Acknowledgments}

L. F. C. Nascimento wishes to thank FAPESP for the provision of grant number 11/06647-0. J. B. Francisco wishes to thank FAPESP for providing a scientific initiation scholarship grant number 11/00836-6.

\section{References}

1. Brook RD, Franklin B, Cascio W, Hong Y, Howard G, Lipsett M, et al. Air pollution and cardiovascular disease: a statement for healthcare professionals from the Expert Panel on Population and Prevention Science of the American Heart Association. Circulation 2004; 109:2655-71.

2. Lopez AD, Mathers CD, Ezzati M, Jamiso DT, Murray CJ. Global and regional burden of disease and risk factors, 2001: systematic analysis of population health data. Lancet 2006; 367:1747-57.

3. Wexler RK. Treatment of hypertension critical in reducing morbidity and mortality. J Am Board Fam Med 2007; 20:322.

4. Brook RD, Brook JR, Urch B, Vincent R, Rajagopalan S, Silverman F. Inhalation of fine particulate air pollution and ozone causes acute arterial vasoconstriction in healthy adults. Circulation 2002; 105:1534-6.

5. Urch B, Silverman F, Corey P, Brook JR, Luzic KZ Rajopagalan S, et al. Acute blood pressure responses in healthy adults during controlled air pollution exposure. Environ Health Perspect 2005; 113:1052-5.
6. Guo Y, Tong S, Zhang Y, Barnett AG, Jia Y, Pan X. The relationship between particulate air pollution and emergency hospital visits for hypertension in Beijing, China. Sci Total Environ 2010; 408:4446-50.

7. Chiarelli PS, Pereira LAA, Saldiva PHN, FerreiraFilho C, Garcia MLB, Braga ALF, et al. The association between air pollution and blood pressure in traffic controllers in Santo André, São Paulo, Brazil. Environ Res 2011; 111:650-5.

8. Ministério do Meio Ambiente. Resolução CONAMA no 03/1990. http://www.mma.gov.br/port/cona $\mathrm{ma} /$ legipesq.cfm?tipo $=3 \&$ numero $=03 \&$ ano $=1990 \&$ texto $=($ accessed on 20/Jul/2012).

9. Gouveia N, Freitas CU, Martins LC, Marcilio IO. Hospitalizações por causas respiratórias e cardiovasculares associadas à contaminação atmosférica no Município de São Paulo, Brasil. Cad Saúde Pública 2006; 22:2669-77.

10. Nascimento LFC. Air pollution and cardiovascular hospital admissions in a medium-sized city in São Paulo State, Brazil. Braz J Med Biol Res 2011; 44:720-4 
11. Nascimento LFC, Francisco JB, Patto MBR, Antunes AM. Environmental pollutants and strokerelated hospital admissions. Cad Saúde Pública 2012; 28:1319-24.

12. Arbex MA, Saldiva PHN, Pereira LAA, Braga ALF. Impact of outdoor biomass air pollution on hypertension hospital admission. J Epidemiol Community Health 2010; 64:573-9.

13. Chuang KJ, Yan YH, Chiu SY, Cheng TJ. Long-term air pollution exposure and risk factors for cardiovascular diseases among the elderly in Taiwan. Occup Environ Med 2011; 68:64-8.

14. Adamopoulos D, Vyssoulis G, Karpanou E, Kyvelou SM, Argacha JF, Cokkinos D, et al. Environmental determinants of blood pressure, arterial stiffness, and central hemodynamics. J Hypertens 2010; 28:903-9.

15. Halonen JI, Zanobetti A, Sparrow D, Vokonas PS, Schwartz J. Relationship between outdoor temperature and blood pressure. Occup Environ Med 2011; 68:296-301.

16. Conceição GMS, Saldiva PHN, Singer JM. Modelos MLG e MAG para análise da associação entre poluição atmosférica e marcadores de morbimortalidade: uma introdução baseada em dados da cidade de São Paulo. Rev Bras Epidemiol 2001; 4:206-19.

17. Lin M, Chen Y, Burnett RT, Villeneuve PJ, Krewski D. The influence of ambient coarse particulate matter on asthma hospitalization in children: case-crossover and time-series analyses. Environ Health Perspect 2002; 110:575-81.
18. Ignotti E, Hacon SS, Junger WL, Mourão D, Longo K, Freitas S, et al. Air pollution and hospital admissions for respiratory diseases in the subequatorial Amazon: a time series approach. Cad Saúde Pública $2010 ; 26: 747-61$

19. Nascimento LFC, Medeiros APP. Internações por pneumonias e queimadas: uma abordagem espacial. J Pediatr (Rio J.) 2012; 88:177-83

20. Gold DR, Litonjua A, Schwartz J, Lovett E, Larson A, Nearing B, et al. Ambient pollution and heart rate variability. Circulation 2000; 101:1267-73.

21. Bartoli CR, Wellenius GA, Diaz EA, Lawrence J, Coull BA, Akiyama I, et al. Mechanisms of inhaled fine particulate air pollution-induced arterial blood pressure changes. Environ Health Perspect 2009; 117:361-6.

22. Ibald-Mulli A, Timonen KL, Annette Peters A, Heinrich J, Wölke G, Lanki T, et al. Effects of particulate air pollution on blood pressure and heart rate in subjects with cardiovascular disease: a multicenter approach. Environ Health Perspect 2004; 112:369-77.

Submitted on 29/Aug/2012

Final version resubmitted on $02 / \mathrm{Jan} / 2013$

Approved on 14/Mar/2013 